\title{
RECEBI A NOTÍCIA DA MORTE DO MEU AVÔ NA SAÍDA DA AULA
}

http://dx.doi.org/10.11606/issn.2237-1184.v0i26p127-128

Lucas Chnaiderman ${ }^{1}$

Neto de Boris Schnaiderman

Recebi a notícia da morte do meu avô na saída da aula. Sou professor no sertão do Rio Grande do Norte. A morte dele não chegou a ser uma surpresa, dado o seu estado de saúde, porém a tristeza foi genuína. Lembro que fui para um canto mais isolado enquanto conversava no celular e chorei sem ruído. 0 que me doía, e o que ainda me dói, é saber que ir para São Paulo, onde agora sou turista, teria sempre associada uma ausência, uma falta.

A notícia da morte do meu avô saiu em vários jornais e vários dos meus alunos vinham me dar as condolências. Espantados, referiam-se ao meu avô como alguém famoso e importante, cuja morte, afinal de contas, sai em todos os periódicos. Às vezes penso sobre isso: na grandeza de sua obra, no pioneirismo de suas traduções e na relevância exuberante de toda sua produção. Conto com orgulho, também, de sua participação na guerra e na resistência à ditadura militar.

Meu avô parece uma personagem quando conto essas coisas, e sua aura de grandeza, exagerada pela distância que a morte proporciona, pode até assustar um pouco. E isso é estranho, pois se houve algo que nunca senti diante do meu avô foi medo. A lembrança desses encontros já me esvai um pouco. É a memória ruim que herdei do meu pai, creio que jamais do meu avô.

Minha mãe sempre conta que meu avô vinha me encontrar frequentemente quando eu era pequeno, e levava-me para passear na rua sem saída em que morávamos. Confesso que não me lembro e tenho ainda mais dificuldades de imaginar esse ato de carinho. Em nossa família paterna não se demonstra carinho, apenas de modo opaco.

Não acredito que eu tenha as lembranças corretas sobre os encontros quando criança. Nem mesmo durante o ensino médio, quando

\footnotetext{
1 Possui graduação em História pela Universidade de São Paulo (2011) e mestrado em História Social pela Universidade de São Paulo (2015). Atualmente é professor EBTT do Instituto Federal de Educação, Ciência e Tecnologia do Rio Grande do Norte, atuando principalmente nos seguintes temas: imprensa, liberalismo e cortes de cádiz.
} 
praticamente todas as tardes passava por sua casa, e bebia do seu café. No entanto, tenho muitas recordações dos seus últimos diálogos. Era sobre a guerra, sempre sobre a guerra, de preferência a Itália. As conversas eram previsíveis, e nem por isso menos emocionantes. Eu, que sou extremamente irrequieto, tinha um prazer sincero de ouvi-lo de forma pausada e com longos silêncios intercalados.

Mais do que as memórias, noto em mim coisas do meu avô, como uma herança cultural passada pelas gerações. Imigrante ucraniano em solo paulista, é possível supor o quanto o peso do estranhamento contribuiu para o ensimesmamento. Meu pai, exilado político da ditadura militar, tem no silêncio uma prática para o presente e para o passado. Eu, paulista radicado no sertão potiguar, às vezes me encontro cada vez mais próximo desse universo.

De forma insólita, os três escolhemos como profissões ofícios dependentes da fala e da comunicação, da docência à advocacia. Penso nele quando estou em sala de aula, assim como penso no meu pai quando trato de política. Penso em meu avô quando leio, e também quando estou em alguma atividade acadêmica. Lembro-me agora que ele foi para minha defesa do mestrado, a foto que tiramos ainda me emociona.

Da primeira vez que estive em São Paulo após sua morte, eu evitei passar pelas mesmas regiões em que convivíamos. Eu, como historiador, sei a força que tem o passado, a potência que tem a memória. Algo não se completa na cidade que por muito tempo chamei de lar. Não é apenas a minha ausência cotidiana que me faz sentir turista na sempre mutante São Paulo, é também uma de suas partes mais seguras que agora desapareceu.

Não sentirei falta do meu avô como tradutor, pois sei que outros virão. Tampouco como professor, pois seus escritos ainda permanecem vivos. 0 que me faz falta no meu avô é sua condição de avô. É o porto seguro que oferecia, é a constância no mundo sempre instável da juventude. Eu sabia como seriam as tardes com o meu avô, sabia sobre o que seria a conversa e como seria o almoço. Tinha quase certeza sobre os momentos de silêncio e também sobre quais assuntos o empolgariam. Sabia que meu pai estava se tornando cada dia mais parecido com ele, e isso me fazia feliz.

É uma contradição rica: alguém que viveu um século catastrófico e instável, oferecia para mim o conforto da segurança e da certeza.

Eu sinto uma falta enorme do meu avô. 